\title{
Traditional Utilization of Aquatic Resources in Eastern Arc Catchments of Tanzania
}

\author{
Agnes G. Kapinga1, Abimbola Sangodoyin², Olayinka 0. Ogunkoya ${ }^{3}$ \\ ${ }^{1}$ Department of Environmental Management, Pan Africa University Life and Earth Sciences Institute (PAULESI), University of \\ Ibadan, Ibadan, Nigeria \\ ${ }^{2}$ Department of Agriculture and Environmental Engineering, University of Ibadan, Ibadan, Nigeria \\ ${ }^{3}$ Department of Department of Geography, Obafemi Awolowo University Ile Ife, Nigeria \\ Email: agnesgisbertkapinga@gmail.com,bimbo_sangodoyin@yahoo.co.uk, olayinkaogunkoya@gmail.com
}

How to cite this paper: Kapinga, A.G. Sangodoyin, A. and Ogunkoya, O.O. (2019) Traditional Utilization of Aquatic Resources in Eastern Arc Catchments of Tanzania. Natural Resources, 10, 153-178. https://doi.org/10.4236/nr.2019.105011

Received: April 14, 2019

Accepted: May 26, 2019

Published: May 29, 2019

Copyright $\odot 2019$ by author(s) and Scientific Research Publishing Inc. This work is licensed under the Creative Commons Attribution International License (CC BY 4.0).

http://creativecommons.org/licenses/by/4.0/ (c) (i) Open Access

\begin{abstract}
Aquatic resources are vital for human well-being particularly to rural communities that largely depend on them for livelihood. Currently, it appears that pressure from human activities related to utilization has impacted negatively on catchment management, particularly of the aquatic resources. This study focuses on the aquatic resources found in the Eastern Arc Catchments of Tanzania which include Upper Zigi and Lower Mngeta. The study employs catchment community participatory mapping approach so as to elucidate how man interacts with and modifies the aquatic environment, the impacts of their behavior, and the responses to changes which occur. The aim of the research is to realize a more comprehensive understanding of water resource management from a cultural, social, economic, political, and biological perspective and facilitate sustainable socio-hydrological interaction model. The study found that there are some similarities and differences in aquatic resources management and utilization among communities. Also, it established that there are more aquatic resources in Lower Mngeta catchment than in Upper Zigi catchment. The study found out that the manner of utilization of aquatic resources depends on their availability, levels of skills, knowledge, and beliefs among members of the communities of the catchments. It was also found that the traditional cultural structures that regulated aquatic resource utilization are weakening at an alarming rate due to factors such as modernization and the establishment of the formal institution. Weak traditional structures contribute in many ways to mismanagement and destruction of aquatic resources. The study recommends that ecological database should not only focus on the resources stock, but also on the dynamics of resources utilization. This would lead identification of appropriate local actors with knowledge and skills and cultural advantage who can be involved in planning
\end{abstract}


and management of these important resources. It would also help to reverse the negative impact already experienced, promote sustainable practices and eventually guarantee the availability of adequate aquatic resources for the present and future generation.

\section{Keywords}

Traditional, Utilization, Aquatic, Resources, Management

\section{Background of the Study}

People are an integral part of the environment of their dwelling places and their activities affect the productive status of these places. Where such places are catchment areas, their productive status affects people's lives as well [1]. In recent years, it appears that pressure from human activities has impacted negatively on natural resources management, and more so, the management of aquatic resources [2]. The information from studies on the linkages between man and catchment resources notes the potentials for the involvement of communities in water resources conservation for sustainable development [2]. Human societies depend on catchment resources to sustain themselves and thrive. In turn, catchment resources depend on human stewardship to maintain their vitality and resilience. That is to say, the linkages between man and aquatic resources have evolved over time and are complicated [3] [4]. The complexity of these connections may differ from one society, climatic zone and region to another due to factors such as catchment hydrology, population dynamics, socio-economic systems including culture, institutions, water-related economic activities, ecosystem services [5] [6] [7] [8] [9], and climate change pattern and characteristics [10]. It is universally known and accepted that the aquatic ecosystem is crucial for nourishing human life and vice versa [11].

Despite the win-win situation existing between man and the environment, man has been modifying the aquatic ecosystem in various ways and, in turn, the change in the aquatic system's ability to provide goods and services elicits changes human behavior and decision-making, relating to the aquatic ecosystem [4]. Regardless of the modification or change that occurs between aquatic ecosystems-man relationships, the competition for resources such as water for man and water for the environment is ultimately mediated by man alone, acting for both himself and the environment [12]. This scenario, in most cases, makes man be greedy, think of himself only and ignore nature. In the short term, man can benefit much by ignoring nature but in the long run, man will start to experience unintended consequences such as salinization, flood, drought, and diseases [13]. The interactions between human and aquatic resources can be well understood in the conceptualization of the socio-cultural and economic aspects of human life in relation to catchment; that is, the complex relationship between man and the natural environment [14]. In recent years, a number of publications have at- 
tempted to explain the connection between nature and human social systems (e.g. [8] [15]-[20]). The literature further shows that the interactions and associated dynamics between people and nature are being influenced by people's values, worldview, norms, belief, thoughts, actions, institutions, livelihood practices, value, attitude, and understandings [14] [20] [21]. However, most of existing conceptual frameworks such as Social-Ecological Systems framework and Ecosystem Services concept do not consider how individual and collective behavior combine to influence the interactions and dynamics in human-nature relationships [14]. Hence, the recommendation by [8] and [14] that more work is required to understand the role of behavior for both individual and collective levels toward understanding the socio-ecological system.

Integrated Water Resources Management (IWRM) is one of the popular approaches used in aquatic resources management whereby, all stakeholders and general public directly or indirectly is actively involved [22]. In the 1990s, the holistic Integrated Water Resources Management (IWRM) approach was worldwide adopted for sustainable catchment resources management. However, different water challenges keep surfacing at alarming rates despite the use of the approach [23] IWRM approach aimed at restricting other rational alternative solution to water problems since the world is heterogeneous and dynamic, with different cultures, systems of governance, social norms, physical attributes, a skewed availability of resources, decision-making processes, types and effectiveness of institutions and investment funds [24]. The problem of ignoring diversities and dynamics is that it reduces the resilience of the system to respond to the uncertainties relating to water use [25]. [24] suggest that in order for IWRM to be real, both national and international organizations will have to address complex conceptual and theoretical questions, but that has not been done so far in meaningful fashion. [24] concluded that the ambiguities of finding optimal solutions that can adequately satisfy all stakeholders are difficult and, therefore, it propose to use water issues instead of water problems. In that regard, this study agrees with [24] by focusing on water issues associated with aquatic resources utilization by involving local stakeholders in identifying diversity of catchment aquatic resources and associated knowledge which may help to eradicate the causes of water problems and that may be sustainable solutions for water problems. This study specifically elucidates the various ways in which local communities utilize the aquatic resources at their disposal using their traditional knowledge with the aim of understanding availability of aquatic resources and various way of utilization of those resources. This also can provide sound strategies for identifying and involving knowledgeable and appropriately skilled local actors in managing resources of catchment areas Understanding how local stakeholders utilize their resources contributes to planning and management and hence reduces the catchment degradation which is a major cause of water problems such as water scarcity and contamination. This may provide good methods and plans for sustainable aquatic ecosystem utilization by promoting a holistic understanding of aquatic resource usage and hence management based on cultural, 
social, economic and political aspects.

In Tanzania the first draft of aquatic habitat ordinance was prepared under Germans colonial rule in 20th century [26]. However, the first water law was not passed until 1923 and then the new ordinance was approved in 1948 and replaced in 1959 under British rule [26]. The laws aimed at securing the access of water for European settlers and limit the use of water by the native people [26]. After the independence in 1961, Tanzania still continues to show the willingness to conserve water resources. Water ordinance of 1959 was amended and replaced by Principal Act No. 42 of 1974. Thereafter, in 1980s Tanzania government adopted a River Basin Management Approach and divided the country into nine basins through Act No. 10 of 1981 which was an amendment of the Principal Act No. 42 of 1974 [27]. The nine basins are Ruvu-Wami, Pangani, Ruvuma and Southern coast, the internal drainage, Rufiji, Lake Victoria, Lake Tanganyika, Lake Nyasa, and Lake Rukwa. In 1991, the National water policy also was formulated before the new one in 2002. The adoption of River Basin Management Approach did not produce the expected results partly because catchment areas were managed by the regional administrations under the local government authorities, while the rivers bodies and their catchments extend beyond administrative boundaries [28]. The current Tanzanian water policy of 2002 and National Water Resource Management Act of 2009 emphasize on the use of river basin authorities for the management of catchment areas. The acts and policy also recognize the importance of balancing livelihood and healthy ecosystem, putting much emphasis on integrated water resources management [29]. Despite the new water management approach, there are still challenges in management of river basin and their catchments. Those challenges include water conflicts and catchments degradation as a result of economic pressure, cultural heterogeneity, climate change, population increase and weak local stakeholder's participation [30] [31]. Therefore, this study believes that characterization of the aquatic resources found in Eastern Arc Catchment of Tanzania, particularly to Upper Zigi and Lower Mngeta can help establish how man interacts with and modifies the aquatic environment, the impacts of their behavior, and how they respond to those changes. This information can be useful in efforts to, promote a holistic understanding of water resource management from a cultural, social, economic, political, and biological perspective and facilitate a sustainable socio-hydrological model. Furthermore, since the characterization of those aquatic resources is through a participatory process, there is adequate opportunity for researchers and practitioners to diverge from the wrong view that local people are external drivers in hydrological systems, to the correct view that people are central to the sustainable exploitation and management of hydrological system [32] [33]. This participatory approach will also help to capture information about needs, skills, experiences, ideas and practices that could lead to practical, relevant, achievable and acceptable solutions for water related problems. This can be realized by creating public trust, facilitating cooperation and avoiding protest and antagonism between local communities and other stakeholders due 
to varying vested interests and demands.

\section{Materials and Methods}

\subsection{Description of the Study Area}

This study was conducted in Upper Zigi and Lower Mngeta sub-catchment located in the Eastern Arc Mountains of Tanzania between January 2018 and May 2018. The Upper Zigi catchment is situated approximately between Latitude $4^{\circ} 48^{\prime}-5^{\circ} 13^{\prime} \mathrm{S}$ and Longitude $38^{\circ} 32^{\prime}-38^{\circ} 48^{\prime} \mathrm{E}$ (Figure 1 ). On the other hand, the Lower Mngeta catchment situated approximately between Latitude $8^{\circ} 0^{\prime}$ $6^{\circ} 77^{\prime} \mathrm{S}$ and Longitude $37^{\circ} 45^{\prime}-12^{\circ} 59^{\prime} \mathrm{E}$ (Figure 2). Both catchments of the study originated from Rainforest Mountains and the weather of these areas is influenced by both the Indian Ocean and the forest [34]. The annual rainfall of the areas is $1780 \mathrm{~mm}$ and $1910 \mathrm{~mm}$ for Lower Mngeta and Upper Zigi catchment respectively; while the average temperature is $27.3^{\circ} \mathrm{C}$ and $20.2^{\circ} \mathrm{C}$ for Lower Mngeta and Upper Zigi respectively [35]. In the Upper Zigi area, the distribution of rainfall is bi-modal, with a climax of rainy season between March to May and another between Septembers to December. On the other hand, the rainfall pattern in the Lower Mngeta catchment is unimodal, which is associated with
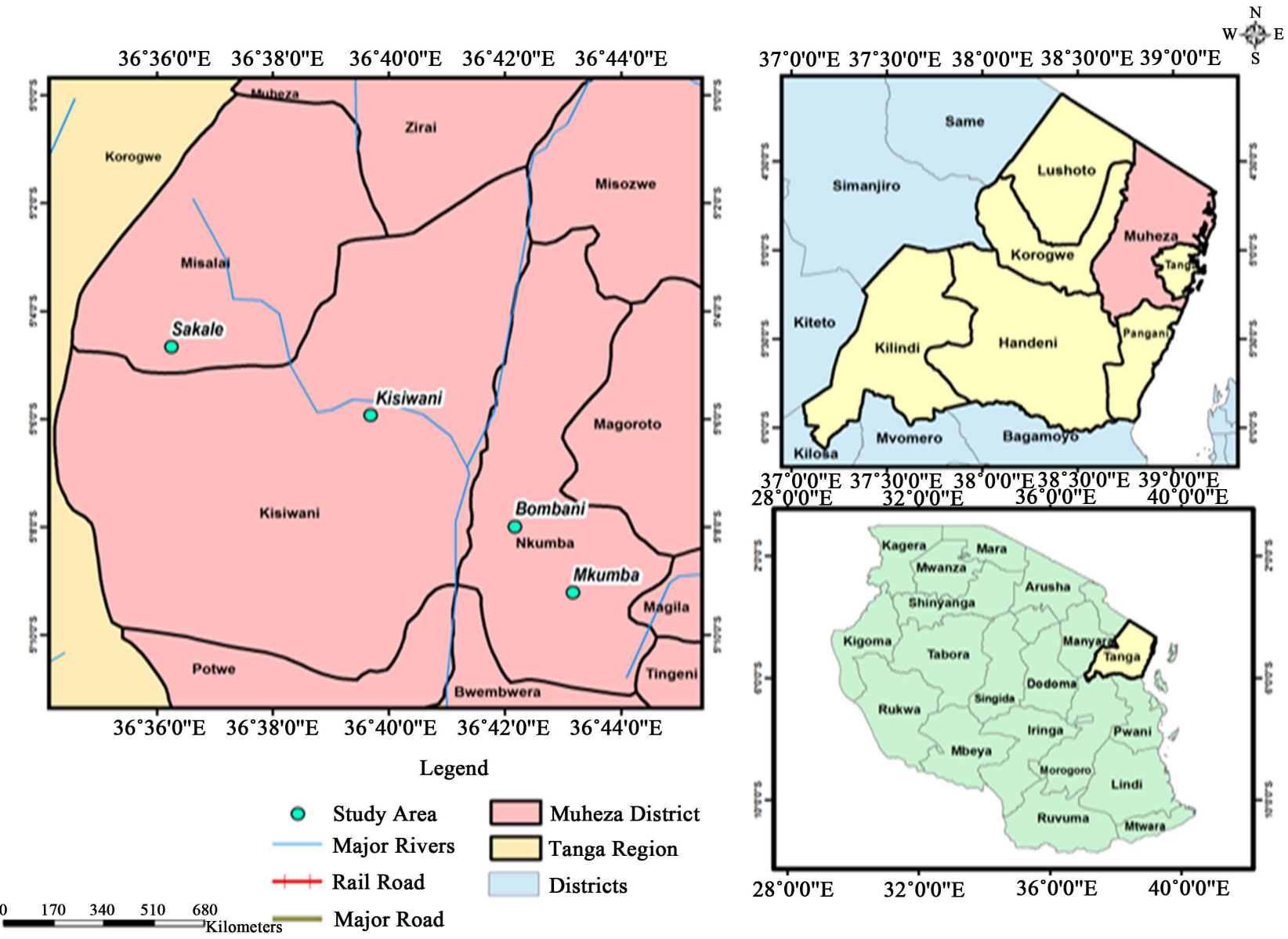

Figure 1. Map for selected villages in upper Zigi catchment. 

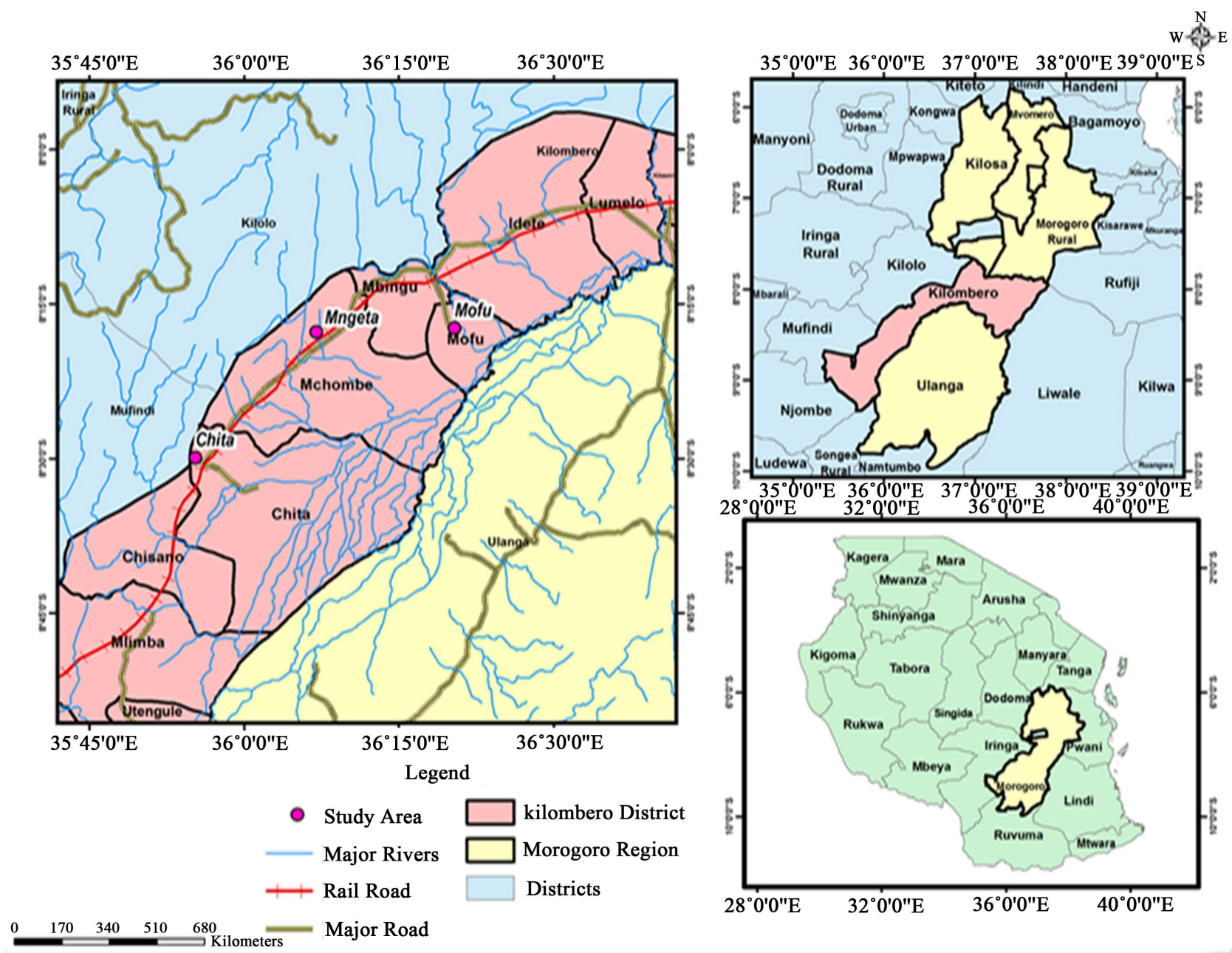

Figure 2. Map for selected villages in lower Mngeta catchment.

heavy rains. The peak of rainfall starts from November to April and then it drops steadily from May onwards. In the Lower Mngeta catchment, floods mostly occur between March and April and sometimes in early January and late May [35]. Floods are commonly associated with the destruction of properties, including crops. The reasons behind this are that Lower Mngeta catchment is located on a floodplain while the Upper Zigi catchment is located on a mountainous area [36]. Unclear onset and ending of rainy seasons, variability and unequal distribution of rainfall patterns are reported as causing the dynamics of livelihood activities in both study areas [36].

\subsubsection{Selection of the Study Areas}

The forests from which the catchments originated are recognized as globally important in terms of carbon sequestrations, centers of species diversity and endemism [37] [38]. However, it is one of the regions of the world facing the most urgent threat in terms of potential extinction of species and degradation [39]. The selection of the catchments was based on cultural and resources diversity. Lower Mngeta catchment was selected based on the fact that it generates ecosys- 
tem services which supports livelihood that attracts people from different cultural background including non-Tanzanian (investors) to settle and invest. On the other hand, selection of Zigi Catchment was due to the fact that the place attracted laborers from in and outside Tanzania to work in tea, sisal and tea plantations. The massive immigration to these catchments makes the place to experience serious deforestation and land degradation caused by timber logging, farm expansion, and livestock grazing. In addition, immigration causes convergence of a diversity of cultures leading to weakening of the original cultural control of the resources utilization. The villages sampled were Mngeta, Mofu, and Chita from Lower Mngeta catchment and Sakale, Kisiwani, Bombani and Nkumba village from Upper Zigi Catchment.

\subsubsection{Demographic and Socioeconomic Situation of the Catchments}

Historically, residents of Lower Mngeta catchment are predominantly Wandamba. However, currently immigrants from other places are integrated with the natives. It was found other tribes such as Hehe, Sukuma, Maasai, Barbaig, Bena, Ngoni, Matengo, Nyakyusa, Ngindo, Muha, Sandawe, Gogo, Safwa, Kulya, Haya, Ndwewe, Pogoro, Digo, and Kinga are currently living in Lower Mngeta Catchment. Massive immigration started in the 1990's when pastoralists, laborers, fishermen, and farmers were looking for pasture, casual labor, fishing activities and land for cultivation respectively [40]. In case of Upper Zigi Catchment, the native residents are predominantly Wasambaa, though, different ethnic groups from different places have currently settled there. Demand for labor in east Usambara tea plantations company (EUTCO), rubber plantation, and farm and non-farm activities have facilitated the immigration and cultural interaction [41]. Immigrant tribes such Bena, Bondei, Chaga, Digo, Kinga, Makonde, Muha, Ndamba, Ndengeleko, Ngoni, Nyamwanga, Nyamwezi, Nyaturu, Pare, Pogoro, Shirazi, Yao, and Zigua are found in the place [41].

Agriculture is the main economic activity employing almost about $80 \%$ and 75\% of study population for Lower Mngeta [36] and Upper Zigi Mngeta [41] respectively. About $45 \%$ and $20 \%$ of total catchment land for Zigi [41] and Mngeta [39] respectively estimated to have farms. The villagers in study areas cultivate both cash and food crops. In Upper Zigi sub-catchment the main and highest income cash crop is cardamom. The other cash crops include cloves, black pepper, and cinnamon. The main food crops are maize, cassava, beans and banana [41]. In Lower Mngeta sub-catchment Rice, maize, peas, and bananas are the main food-cum-cash crops while sugarcane, sesame, sunflowers, rubber, and cocoa are grown for commercial purposes [36]. The community is also practicing the livestock keeping: In upper Zigi mainly done on zero grazing bases [41], while in Lower Mngeta is done on bases of nomadism and few in zero grazing [31]. The nomadic pastoralism result to conflict among villagers, particularly with reference to crop destruction [32]. Additionally, the increase in livestock population in Lower Mngeta sub-catchment reported causing significant 
destruction of wild animals habitats which also has implication in reduction of wild animals habitats such as buffalo, puku, elephants along with soil degradation [32] and compaction, altering the eco-hydrological character of the floodplain area [32].

\subsection{Methodological Approach}

The study employed participatory rural appraisal (PRA). PRA is highly contextualized since research methods adopted for the current study are geared towards sharing the research process with the participating communities and also pay more attention to contextually specific knowledge using qualitative method [42]. The qualitative methods allow for conductive reasoning, interaction and reflection, and taking into account the context and cultural background of respondents [43]. According to [43], PAR is a design that departs from conventional disciplinary research characterized by a separation of researcher and researched. Instead, people in communities are recognized as experts in their own development process and as co-owners and active participants of the research and inquiry process and not passive subjects. As this study elucidates the links and dynamics between hydrological catchments and human social systems, this design facilitated the local communities to map their catchment resources, identify the changes and causes, and to recognize the importance of the different people in relation to the catchment resources. As a result the community recognized the wealth of assets that belong to them and that can bring out changes.

\subsubsection{Participatory Resource Mapping (PRM)}

The resource mapping technique was used to identify which aquatic resources are used for which purpose, which place the resource is found, who uses them and who depends on them. The participants sampled from each village drew a map on pieces of paper which demonstrated the scope of community territories and illustrated the significance of the territories and associated resources for the lives of local communities. Markers of different colors were used to characterize different resources for easy identification. For enhancement of collaborative discussion during the process, facilitation was done by the researchers. PRM empowers communities to articulate their knowledge of the surrounding physical environment [44]. According to [45], the involvement of and collaboration with indigenous or local people in the production of maps of the local physical environment helps to discover traditional spatial knowledge, and a dialectical exchange between the participants and researchers. In each village people who participated in resource mapping were selected by fellow members during the village meeting to represent the entire community (Mngeta $=50, \mathrm{Mofu}=55$, Chita $=42$, Sakale $=45$, Kisiwani $=42$, Bombani $=34$, and Nkumba $=37$ ). Mapping was conducted in groups of 10 to 15 people each. The selection of participant was based on the familiarity of area, gender, and size of village hamlets. To be selected, representative needed to have stayed in village for at least 15 years. 


\subsubsection{Focus Group Discussion}

The same people who participated in participatory mapping were also subjected to the focus group discussion. The Focus Group Discussion (FGD) was conducted by using checklists in each village of the study. The team for FGD comprised both men and women. For the credibility and making sure that every participant contributes something, the focus group discussion was conducted in groups of 10 - 15 people per group. The variables captured in FGD were socio-economic and cultural practices that are connected with aquatic resources and the traditional norms regulate the interaction between human and aquatic environment.

\subsubsection{Basic Demographic Characteristics of Participants}

Participants in participated in PRM and FGD were both men and women as described in Table 1 with the age ranged from 22 to 86 . The main economic activities were farming and livestock keeping. Farmers were $93.2 \%$ and $98.7 \%$ in Lower Mngeta and Upper Zigi respectively, while pastoralists were $6.8 \%$ and $1.3 \%$ in Lower Mngeta and Upper Zigi respectively.

\subsection{Data Analysis Techniques}

Content analysis was conducted in a view to preserve meanings of phenomena as intended by the local community under study. According to [46], the content analysis deals with systematic coding, categorizing and interpretation of textual data and helps a researcher to determine trends, patterns, themes and the relationships of the particular phenomenon under the study. The types of bio-cultural resources and its utilization were broken into meaningful units of information or themes. Note taking and voice recording was done during and soon after

Table 1. Participants in participatory resource mapping and Focus group discussion.

\begin{tabular}{ccccc}
\hline Sub-Catchment & Village & \multicolumn{2}{c}{ Participants } & \\
\hline Lower Mngeta & Men & Women & Total \\
& Mngeta & 32 & 18 & 50 \\
Mofu & 30 & 25 & 55 \\
Chita & 24 & 18 & 42 \\
Total & 86 & 61 & 147 \\
\hline Upper Zigi & Men & Women & Total \\
& Sakale & 19 & 26 & 45 \\
& Kisiwani & 30 & 12 & 42 \\
& Bombani & 21 & 13 & 34 \\
& Nkumba & 25 & 12 & 37 \\
\hline
\end{tabular}


conversation respectively with the participants. The researcher tried to recall the entire conversation figuring out what major themes or topics emerged. The observed themes were noted in separate sheets. Then, on each theme, the researcher recorded everything that could be remembered. The analysis has six phases. In the first phase, recorded data about the availability of catchment resources and how the community utilizes them, and the historical use of catchment resources were reviewed and studied through intensive reading and transcription of verbal into written format. This phase was important because it helped to generate a list of ideas based on interest, and to articulate the possible meaning about them.

In the second phase, the initial codes were generated by creating short sentences that explain the phenomena by looking for idea generated from each research question. The codes were divided into four groups, those from social, political, cultural, and economic in relation to the use and management of catchment resources. The third phase was all about sorted codes and combines them based on similarities and differences to form patterns, relationship, and concepts, and reorganized based on potential themes. The identified categories of codes were combined to form three main themes. In phase four, identified themes were cross-checked by fusing those with similarities and disaggregating those with dissimilarities. The process of cross-checking was possible through the guidance of the research questions. In the fifth phase, the themes were described by looking at what themes are all about and which the aspects of data that themes were captured. The final phase was reporting.

Quotation and paraphrasing were also used in qualitative data analysis of narratives and folklores on different phenomenon in the study. This was particular to data that related to management of catchment resources using norms, taboos, rules, and folkways. During analysis only code names were used in order to protect privacy of the participants.

\section{Results and Discussions}

\subsection{Characterization of the Current Aquatic Resources}

In this study aquatic resources refer to any natural resource found in aquatic environment and has value to human beings. These resources are determined by human being and not by nature. Two conditions must be adhered to in classifying an element as a resource: First, the knowledge and technical skills must be in place to allow its extraction and utilization; second, there must be demand for materials or services produced [47].

Several permanent and seasonal rivers and ponds were mapped in Lower Mngeta catchment. In case of Zigi, only rivers were mapped. The river and pond habitats provide both materials and non-materials resources such as water, plants, insects, fish, wild animals, and rituals sites. It was observed that there was a slight difference in resources identification and usage within the catchments of 
this study. River and pond habitats are more valued by Ndamba ethnic group (the native people) in Lower Mngeta catchment because they are associated with their mode of subsistence and cultural beliefs unlike ethnic groups in Upper Zigi catchment who mostly value river habitats mostly because of their cultural belief. For stance; in Lower Mngeta Catchment community particularly the Ndamba ethnic group believes that killing the hippopotamus is a symbol of heroism. Also, frogs are used for predicting rainy season, but also, are used to indicate the presence of predator animal and to determine the water level. Contrary to this, Upper Zigi catchment used frogs to test the efficacy of poison used for hunting. [48] reported that cultural links between humans and nature have a central influence on people's values and sustainable use of natural resources and hence conservation. This result provides a sight that the aquatic habitats conservation measure should integrate both mode of substance and beliefs in relation to aquatic habitats. The importance of doing so is to avoid generalization and to be specific in solving the problems.

The outstanding finding between catchments is that Lower Mngeta aquatic environment has more aquatic resources as compared to the Upper Zigi catchment. However, there were similarities and differences in aquatic resources availability and utilization between catchments as shown in Table 2. Aquatic bio-cultural resources that are found only in Lower Mngeta catchment were crocodile, hippopotamus, Weed (Water Cabbage), otter and tortoise, while, crab was found only in Upper Zigi catchment. The differences and similarities in aquatic resources availability and utilization are supported by [41] who documented that utilization of natural resources depends on the needs of community but also what ecosystem can offer. In addition [49], reported that knowledge and cultural practices which depend on specific natural resources have influence on resources utilization. This implies that it is difficult to explore aquatic resources diversity using only language and species composition as suggested by [50] [51] [52]. This is due to the fact that nowadays the world is much connected in such a way there is similarity in linguistic and cultural due to people movements that may lead to language distortion, culture and knowledge infusion. On top of that, environmental degradation and changes may diminish some of species which were available in the ecosystem. Furthermore, if it is to focus only on the language with many speakers is to ignore the outliers' ethnic group which is crucial in diversity. Also, it should be clear that despite the ethnic languages people belong to, almost every community and individual Tanzanian speak Kiswahili; this means that using only language as proxy for cultural diversity with regard to aquatic resource utilization is not ideal in Tanzania due to uniformity. The result is line up with study by [53] who found that in arctic region diversity of ecosystem resources (Biological and cultural resources) were determined by societal boundaries and territorial border and not language, because people speak the same language but differ in notation, rhythm, and speed of speech. 
Table 2. Uses of bio-cultural resources which are found in rivers and ponds.

\begin{tabular}{|c|c|c|c|}
\hline Resource & Use & $\begin{array}{l}\text { Lower Mngeta } \\
\text { catchment }\end{array}$ & $\begin{array}{l}\text { Upper Zigi } \\
\text { Catchment }\end{array}$ \\
\hline \multirow{10}{*}{ Water } & Purification, believed to have misfortune & $\sqrt{ }$ & $\sqrt{ }$ \\
\hline & Domestic use & $\sqrt{ }$ & $\sqrt{ }$ \\
\hline & Swimming & $\sqrt{ }$ & $\sqrt{ }$ \\
\hline & Transportation/Navigation & $\sqrt{ }$ & - \\
\hline & Irrigation & $\sqrt{ }$ & $\sqrt{ }$ \\
\hline & Hydropower generation & $\sqrt{ }$ & - \\
\hline & $\begin{array}{l}\text { Welcoming baby out after } 40 \text { days } \\
\text { (rituals for newborn babies) }\end{array}$ & - & $\sqrt{ }$ \\
\hline & $\begin{array}{l}\text { As demo on how to do sex for teenagers } \\
\text { (site for demonstrating } \\
\text { sex education for teenager) }\end{array}$ & - & $\sqrt{ }$ \\
\hline & Baptism & $\sqrt{ }$ & $\sqrt{ }$ \\
\hline & Calling ghost during rituals & $\sqrt{ }$ & - \\
\hline \multirow{10}{*}{ Fish } & Food & $\sqrt{ }$ & $\sqrt{ }$ \\
\hline & Fish oil for treating ears & $\sqrt{ }$ & $\sqrt{ }$ \\
\hline & Fish oil for energy provision to sick people & $\sqrt{ }$ & $\sqrt{ }$ \\
\hline & Tilapia for sacrifices & $\sqrt{ }$ & - \\
\hline & $\begin{array}{l}\text { Catfish for making some on } \\
\text { slippery during fighting }\end{array}$ & $\sqrt{ }$ & $\sqrt{ }$ \\
\hline & $\begin{array}{l}\text { "Mkunga" fish for making someone } \\
\text { slippery during fighting }\end{array}$ & $\sqrt{ }$ & $\sqrt{ }$ \\
\hline & Catfish for treating ovulation disorder & - & $\sqrt{ }$ \\
\hline & Shells of catfish are used to treat convulsion & - & $\sqrt{ }$ \\
\hline & Small fish used as bait & $\sqrt{ }$ & $\sqrt{ }$ \\
\hline & Tilapia for making medicine for cleverness & $\sqrt{ }$ & - \\
\hline \multirow{6}{*}{ Crocodile } & Eggs as a source of food & $\sqrt{ }$ & - \\
\hline & Tail part as a source of food & $\sqrt{ }$ & - \\
\hline & Fat oils for treating ulcers & $\sqrt{ }$ & - \\
\hline & Skins were used to make drums & $\sqrt{ }$ & - \\
\hline & Bile were used as strong poison & $\sqrt{ }$ & - \\
\hline & For witching & $\sqrt{ }$ & - \\
\hline \multirow{4}{*}{$\begin{array}{l}\text { Monitoring } \\
\text { Lizards }\end{array}$} & Eggs as a source of food & $\sqrt{ }$ & - \\
\hline & Its skin for making drums & $\sqrt{ }$ & - \\
\hline & Oil to treat ears pain & $\sqrt{ }$ & $\sqrt{ }$ \\
\hline & Business (as a live animal trade) & - & $\sqrt{ }$ \\
\hline \multirow{3}{*}{ Hippopotamus } & Food & $\sqrt{ }$ & - \\
\hline & Making hard stick "Ndomondo" & $\sqrt{ }$ & - \\
\hline & Symbol of heroism & $\sqrt{ }$ & - \\
\hline
\end{tabular}




\section{Continued}

\begin{tabular}{|c|c|c|c|}
\hline \multirow{3}{*}{$\begin{array}{c}\text { Weed } \\
\text { (Water Cabbage) }\end{array}$} & $\begin{array}{l}\text { place on water top to protect water } \\
\text { from sun (protects water from direct sun rays) }\end{array}$ & $\sqrt{ }$ & - \\
\hline & For salt manufacturing & $\sqrt{ }$ & - \\
\hline & Medicine for tonsils treatment & $\sqrt{ }$ & - \\
\hline \multirow{2}{*}{ Sea Otter } & Source of Food & $\sqrt{ }$ & - \\
\hline & Skin is used as a medicine for treating big wounds & $\sqrt{ }$ & - \\
\hline \multirow{7}{*}{ Reed } & For constructing fences & $\sqrt{ }$ & $\sqrt{ }$ \\
\hline & Supplies roofing materials & $\sqrt{ }$ & $\sqrt{ }$ \\
\hline & For making fishing traps & $\sqrt{ }$ & - \\
\hline & For making doors and windows & $\sqrt{ }$ & $\sqrt{ }$ \\
\hline & For making tray for keeping dishes & $\sqrt{ }$ & - \\
\hline & Alternative of fire wood & $\sqrt{ }$ & - \\
\hline & For hanging fish in drying time & $\sqrt{ }$ & - \\
\hline \multirow{7}{*}{ Frogs } & For rainfall forecasting & $\sqrt{ }$ & $\sqrt{ }$ \\
\hline & Determine the level of water in rivers and ponds & $\sqrt{ }$ & - \\
\hline & $\begin{array}{l}\text { Their sounds are used to } \\
\text { predict predictor animals }\end{array}$ & $\sqrt{ }$ & - \\
\hline & Used as baits & $\sqrt{ }$ & - \\
\hline & For treating swelling legs & - & $\sqrt{ }$ \\
\hline & Commercial value( A live animal) & - & $\sqrt{ }$ \\
\hline & For testing the levels of poison & - & $\sqrt{ }$ \\
\hline \multirow{5}{*}{ Sand } & Building material & $\sqrt{ }$ & $\sqrt{ }$ \\
\hline & Washing utensils & $\sqrt{ }$ & $\sqrt{ }$ \\
\hline & Seed germination & - & $\sqrt{ }$ \\
\hline & $\begin{array}{c}\text { First aid for someone } \\
\text { immersed in water (not clear) }\end{array}$ & - & $\sqrt{ }$ \\
\hline & Used for frying groundnuts & - & $\sqrt{ }$ \\
\hline \multirow{3}{*}{ Crab } & As a source of food & - & $\sqrt{ }$ \\
\hline & Medicine to treat asthma & - & $\sqrt{ }$ \\
\hline & Used as baits & - & \\
\hline \multirow{2}{*}{ Tortoise } & As a source of food & $\sqrt{ }$ & - \\
\hline & Business (Commercial value) & - & $\sqrt{ }$ \\
\hline
\end{tabular}

Note: 1) $(\sqrt{ })$ means people recognize its use/value; 2$)(-)$ mean didn't state the uses/value.

\subsection{Socio-Cultural and Economic Activities Associated with Aquatic Environment}

1) Ritual and Sacrifices

The connection between aquatic habitats and cultural-spiritual centers within Mngeta and Zigi community were found during the study. In both catchments, the community believes that some places in or around rivers are occupied by the 
Ghosts. These places are termed as sacred sites and are much respected and protected by the community members. On top of that, some community members who are tradition healers in both catchments believe that flowing water help to cast diseases like skin rashes, misfortunes, and curses such as miscarriages, unemployment and lack of acceptability to the community. Patients are submerged in water so that they can be healed.

Sakale village in Upper Zigi Catchment was found to have a spring where clay pot was placed near Kihara River. This place is believed to have spiritual powers. The village elders are allowed to do rites around the place on behalf of the community members. This place is not allowed to be reached by anyone except only the authorized elders because the village ghost is living in that area. It is believed that entering this area without permission may cause water in all rivers to be dirty and whoever is involved might die or disappear from the community. To mitigate the punishment from the village ghost, the authorized village elders are doing rituals in which blood from a goat is spread around the pot.

The rituals and sacrifices systems of Ndamba who are native people of Lower Mngeta catchment are also connected with rivers. In Mngeta catchment there are cultural-spiritual rivers named Mngeta and Mchombe which are found in both Mngeta and Chita villages and Lwipa in Mofu village. The rituals accompanied by sacrifices are done in and around the river for the purposes of seeking help from the fore ghosts so as to find solution for difficult moments/problems such as floods, drought, diseases, misfortunes, and accident from predator animals such as crocodiles and lions. Rituals which are conducted in rivers are for individuals, family, clan and the whole village community. In additional, thanksgiving rituals are conducted in river habitats at the beginning and end of each year.

The finding elaborates that the functions of river are to purify and cleanse the spiritual and physical contaminations, and also to act as the media for communication with their gods/ghosts. Moreover, communities around those water catchments values water and its habitats based on their world-view and perception inherited from their elders. Passing beliefs and practices from one generation to another may help to conserve the water resources easily at low cost by using traditional institution. It was reported that wishes due to the practices can be possible if someone who is practicing the action has strong beliefs and follows the taboos accordingly. The finding is in line with [54] who reported that several places of rituals importance are located on the Tapi river banks of India. [55], also found that saltwater was used by residents of Hilo in Hawaii for cleansing and purifying their spirituals and physical contamination; and also freshwater for rites to bring water/rainfall when the land is dry. [54] recommended that rivers should not be considered only as materialistic object but also as a symbol of entire life that is tied with strong beliefs.

2) Swimming

The swimming practices are done using the body or boats. Traditionally, any men from Ndamba tribe in Lower Mngeta catchment were allowed to know how 
to swim. Ndamba women and other tribes who were not Ndamba but lived in Lower Mngeta catchment were also advised to learn how to swim. The main reason why Ndamba men are necessitated to know how to swim is that they are fishermen; swimming is a necessary skill that could help them when water accidents/incidents occur. The other reason was revealed in Mofu village, that most of villages in Lower Mngeta catchment are located in flood plain areas, the area is mostly affected by floods thus swimming skills are of paramount importance to rescue themselves from death during floods. Swimming is also done for refreshment or part of physical exercise mostly during the dry season when rivers are not flooded hence water levels are low. On the contrary, in Upper Zigi catchment, swimming was only done by children in rivers during rainy season when water level is high.

The above-mentioned reasons concur with the study by [56] who reported in Victorian Britain who reported swimming was a cultural and a safety practice, apart from refreshment, it boosted the of muscularity and means of secure from water death. This finding signifies swimming as a cultural capital for Ndamba ethnic group (native in Lower Mngeta) and any man who couldn't know how swim deemed as reliable to the community. This is in line with [57] who reported that citizenship has positive correlation with swimming participation.

This study identifies weakness in swimming activities in Ndamba ethnic group by revealing that, the swimming practices were encouraged more to men than women. This finding is inverse to the finding in South of England by [57] who reported women associated positively with swimming. This implies that in Lower Mngeta catchment when water accident such as flood or ordinary drowning occurs, women have high chance of dying than men.

Despite the importance of swimming to the members of the community, during the FGD it was revealed that swimming had much reduced in both catchments. The reasons for reduction were frequency of crocodile accident which was expressed only in down Mngeta Catchment, and presence of Ramser site laws and marine resources management restrict economic activities and other recreational activities to take place in marine habitats was reported in both study areas. The decline of swimming practice has negative implication for the well-being and quality of community's life since decline of swimming means decline in physical fitness and safety of communities. This is supported by [58] who reported there is important for responsible institution to maintain and improve swimming knowledge for water safety.

3) Fishing

Historically the Mngeta catchment was occupied by fishermen who were Ndamba and fishing was done only by men. If a Ndamba woman was doing fishing activities all community looked down at her. The activity was conducted in ponds and rivers using traditional traps called "mgonyo" (Figure 3) and "Manga" which are made of either reed or bamboo and ropes; spears, boat, and hooks also were used. The arrival of other tribes particularly Nyakyusa, Hehe, Bena and Pogoro and hardships of their life made fishing to lose gender 


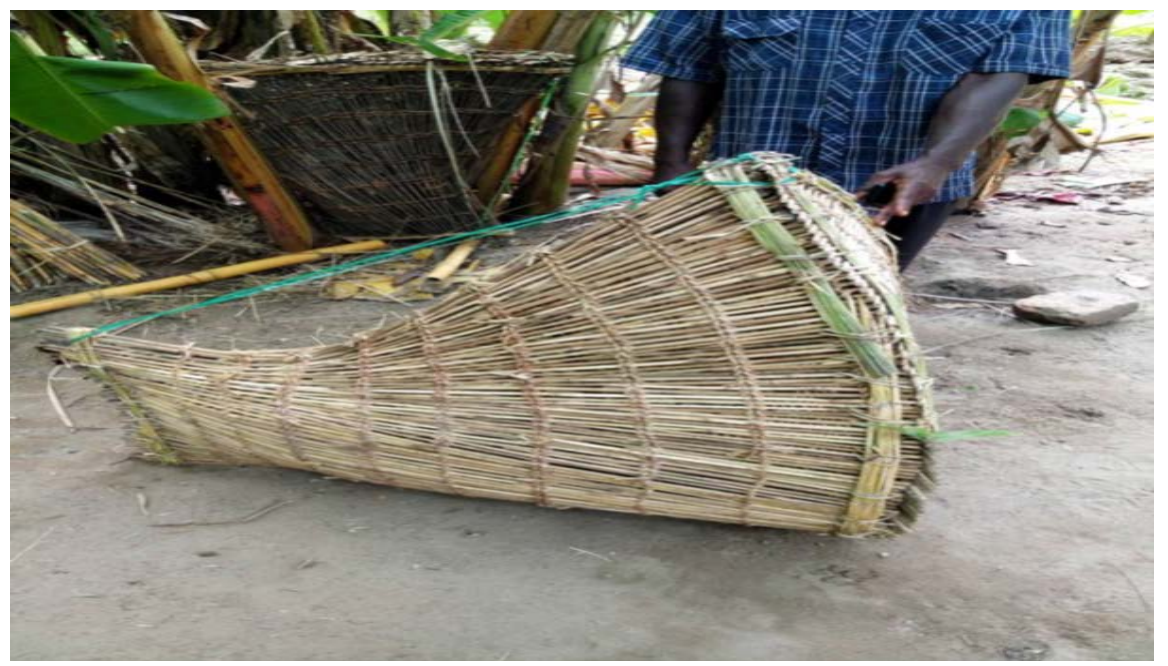

Figure 3. The fishing trap "mgonyo" in Lower Mngeta Catchment: Photo taken in April 2018 by Eric Ildefonce during data collection.

specifications. The activity was conducted either by groups or individuals although groups were preferred for security purpose. Up to 1980's, men from Ndamba ethnic were mainly involved in fishing activity. Farming was conducted only by women in small scales. From 1990's up to date, it has been reported there are gradual changes of fish resources availability in terms of size and quantity. The changes make men from Ndamba society engage in other income generating activities. This is also reported in [59] who said that due to the fishing activities, there is positive association with high livelihood activity diversification, specifically in agriculture. Furthermore, recently women have been reported to increasingly involve in fishing activities.

In Lower Mngeta catchment the way men were doing fishing was different from how women did it. Firstly: The women mainly fish in shallow water, while, men fish in deep water; secondly: Most men use ritual in fishing while the women very rarely use ritual; and thirdly: Women use simple tools in fishing such as small nets called "makokoro", herb called "mtupa" and basket. Culturally, it was assumed that women's fishing was not as important as men's and little attention was given to it. The assumption is going against the reality that women contribute to marine food yield and make significant contribution to food security [60]. Since fishing skills is heritage the women should get involve full in the fishing activities because are the best teachers to the family and society. This will help conservation of marine resources and at the same times improving the protein intake.

In Upper Zigi catchment fishing was conducted in a small scale by few people mostly using hooks and herb poison. The reason behind is that the native people of the area were peasant farmers. In addition, the topography of the area does not much favor the growing of fish since it is mountainous area with small rivers and streams. Currently, it is reported the fishing activities is very low due to low availability of fish. 


\section{4) Farming}

Traditionally, there was no farming conducted near the river banks due to strong beliefs and norms governing aquatic environment. Currently, the farming is conducted around the rivers and stream banks for easy accessibility of water and soil humidity despite the fact that it is illegal according to the Tanzania water laws and Ramsar laws with regard to wetland management. Currently, horticulture a production is conducted in aquatic environment using irrigation techniques in both areas of study. Fore stance, Figure 4 shows horticulture plots along Zigi River in Upper Zigi Catchment. Furthermore, rice and spices farming in Lower Mngeta and Upper Zigi catchment respectively are conducted too. During participatory mapping in Upper Zigi catchment it was revealed spice farmers since 2000s are gradually shifting to river banks due to draught. They were saying spice farming particularly cloves, cardamom and cinnamon do better when there is high level humidity. The introduction of exotic spices to the aquatic environment may lead to destruction of ecosystem equilibrium. The movement of spices farmers from terrestrials to aquatic environment may be due to good market availability as reported by [61]. The reasons for cultivation is similar to [15] who reported the Zaka community in Zimbabwe prefers to cultivate on stream banks due to several factors such as draught mitigation, fertile alluvial soils, closeness to water sources and local land pressure.

It was also reported that crop farming around river and stream banks are more vulnerable to fungal diseases specifically to horticulture products. Furthermore, the siltation was much reported in Lower Mngeta catchment like the study by [61] and [62]. The environmental assessment should be conducted to

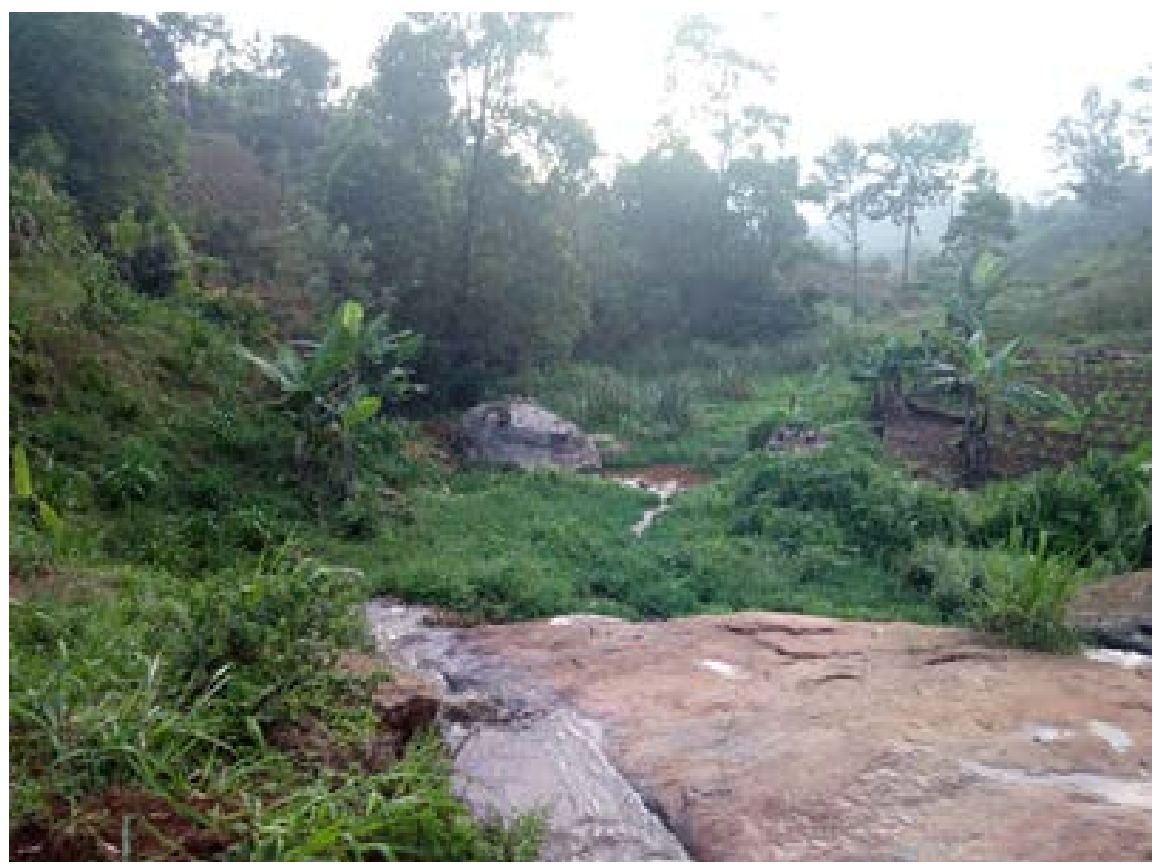

Figure 4. Some agriculture plots in Zigi River banks: Photo taken in May 2018 by Eric Ildefonce during data collection. 
be able to understand well all cost and benefit associated with farming within river and stream banks and if there are possible sustainable ways of conducting the farming activities, the community should legally be allowed to farm around the bank because is support community livelihood specifically in this time of climate change and variability.

5) Bathing and washing

Bathing and washing are also conducted in the river and stream. In Upper Zigi catchment bathing in river was reported to be practiced mostly by children as depicted in Figure 5, while in Lower Mngeta catchment both adult and children were practicing it. It was reported that bathing and washing had decreased at study areas because of the availability of water in the street. Nowadays few people are still going to rivers and streams for washing and bathing compared to the past years. The detergents used for bathing and washing may disturb and even kill the aquatic organism. This was also supported by who reported [63] bathing and washing destroy the quality of water.

\subsection{The Traditional Norms Regulates Interaction between Human and Aquatic Environment}

For a long time, traditional norms such as taboos, customs, morals, and folkways are reported to regulate human behaviors towards use of catchment resources. Although, in recent days emphasize the formal institution in managing natural resources made traditional norms to have less power. Similarities and differences

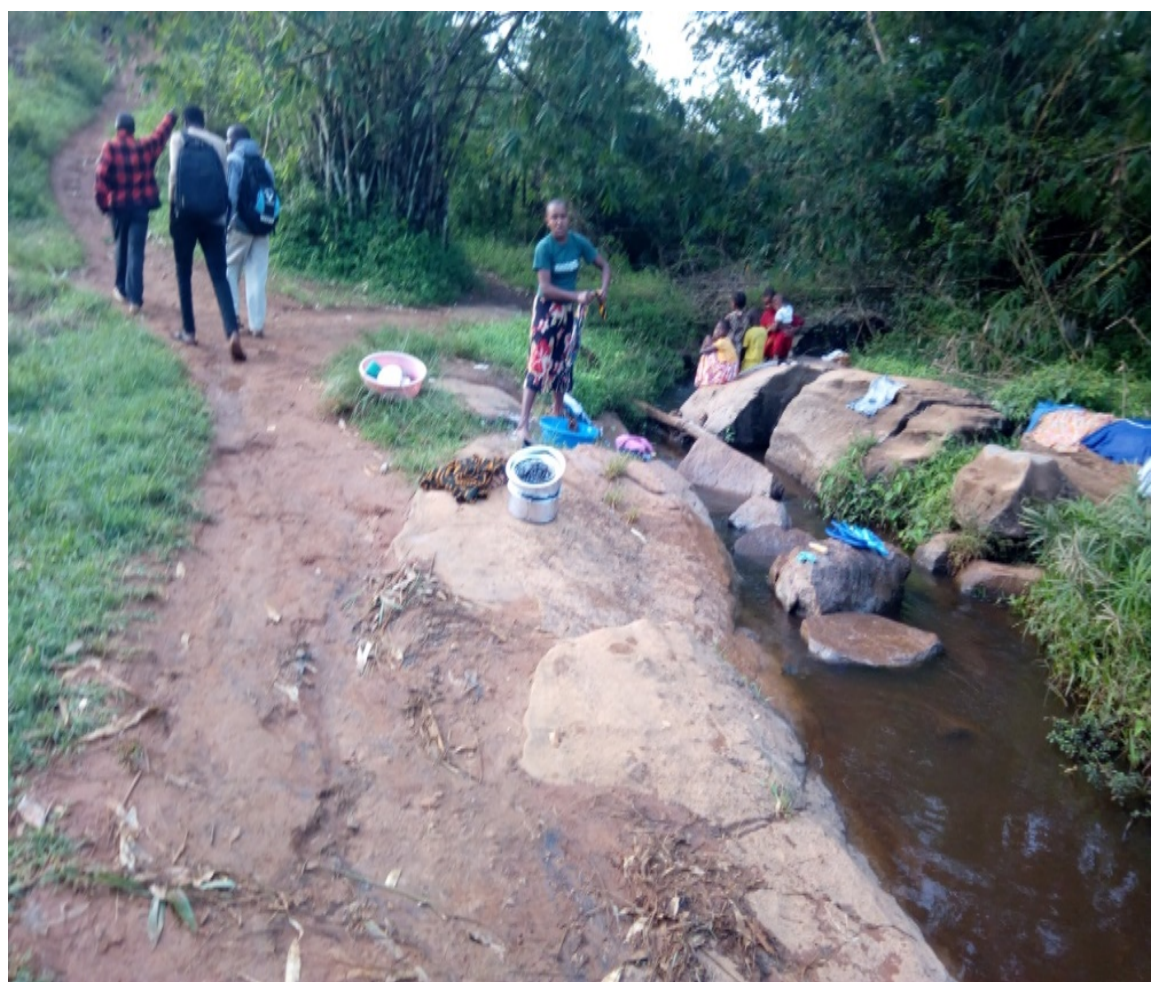

Figure 5. Clothes washing practice in Upper Zigi catchment in Sakale village: Photo taken in May 2018 by Agnes Kapinga during data collection. 
of traditional norm regulating aquatic resource utilization were found as described in Box 1(a) and Box 1(b). The norms set associated with cultural beliefs that regulate their relationship with the ancestral spirits and the deity who believed to live in river areas. Majority of norms mentioned are relating directly to the natural resources management except for the few ones. The norms practiced can be grouped into three; that is avoiding, monitoring and temporary restriction. Norms provide moral guidance toward resources utilization and conservation by preventing people's behaviors and practices that lead to ruin the health of the catchment ecosystem. Violation of norms was accompanied by punishment and most of them were the one associated with belief such as death, getting lost, misfortune and heath such as madness. People who were sanctioned because of norms violation had to get purification by doing rituals. The rituals were all about asking for mercy from their ghosts. It should be noted that, currently, these norms mentioned in Box 1(a) and Box 1(b) are not well obeyed and respected. [64] emphasize that effective conservation can be met if traditional institutions and formal conservation agent collaborate; since nature cannot be treated in isolation from social system.

\section{Summaries and Conclusions}

This study articulates how local stakeholders utilize their aquatic resources as universally acknowledged. Local stakeholders are the primary users of resources and they tend to use natural resources in different ways [65] [66]. Hence, it is essential to hear directly from them on how they value the resources before starting other management issues. The study brings out the platform and common understanding to other aquatic actors so as they can work and plan together with local actors on sustainable management of aquatic resources. This can help the quality of local stakeholders' participation in sustainable aquatic ecosystem management to be fulfilled and to enhance the improvement of the equal distribution of aquatic resources benefits and reduce stakeholders' conflicts. In these study areas, the utilization of aquatic resources is triggered by the availability of resources, skills knowledge, belief as well as a mode of substance. For instance, the community in Lower Mngeta catchment value more aquatic habitats since it conveys both mode of subsistence and cultural beliefs unlike ethnic groups in Upper Zigi catchment who mostly value aquatic habitats because of their cultural belief. This tells that establishing a framework for aquatic resources management while ignoring resources local valuation is like trying making a budget or plan for something without knowing exactly its value.

In these study areas, there are some similarities and differences in aquatic resources utilization. Also, more aquatic resources found in Lower Mngeta catchment than Upper Zigi catchment. The reason behind might be due to the fact that Lower Mngeta catchment is wetland area, while Upper Zigi is located the mountainous areas. That means some of the methods of conservation that might be helpful in one catchment cannot work out in another catchment due to the difference in resources availability. Social cultural practices such as swimming 


\section{Sakale village}

- It is not allowed to go to the river with smoked/ soot appliances. .

- It is not allowed to cross river if you are not circumcised

- It is not allowed to move with fire across the rivers.

- Women in their menstruation periods are not allowed to cross the river

- It is not allowed to bring salts in or around the rivers

It is not allowed to carry iron tools around rivers sites

- It is not allowed to cut tree around the rivers without permission from elders. Only branches were allowed.

\section{Kisiwani Village}

It is not allowed to go to the river with smoked/ soot appliances.

- It is not allowed to cross river if you are not circumcised

- It is not allowed to cross with fire across the rivers.

- It is not allowed pea or poo in the river.

- It is not allowed to cut tree around the rivers without permission from elders.

\section{Bombani village}

- It is not allowed to go to the river with smoked/ soot appliances.

It is not allowed to cross with fire across the rivers.

- It is not allowed to bath in rivers

- It is not allowed not allowed fetching water while they were naked.

- It is not allowed to do fishing in wells.

\section{Nkumba villages}

- It is not allowed to go to the river with smoked/ soot appliances.

- It is not allowed to fetch water while they were naked

(a)

\section{Mngeta Village}

It is not allowed to go to the river with smoked/ soot appliances.

It is not allowed to have sex nearby or inside the rivers.

It is not allowed to wash clothes or domestic appliances inside the rivers.

It is not allowed to use any cosmetic soap or anything in relation to cosmetics inside or around the rivers.

It is not allowed to cut grasses and/or trees nearby rivers.

It is not allowed to dump anything dirt inside the river.

At community level there was a specific date for fishing. Village elders are in charge of supervising the activities.

At individual level, before a person go to the river site, a person should specify on his own heart through special prayers the species, number of fish he want to fish and reason to go for fishing.

Mofu village

- It is not allowed to bring kerosene to the rivers or ponds

- It is not allowed to bring any kind of soap to the rivers or ponds.

It is not allowed to start settlement in river banks.

- It is not allowed to have sex nearby or inside the rivers.

- Fishermen when they are going to fish, they are not allowed to wear trousers. Instead special clothing wrapper in dark color called "Luvangu".

- It is not allowed to cut grasses or/ and trees nearby rivers and ponds.

- At community level there is a specific calendar for fishing. From June to September fishing was done in rivers. Then, from January to May fishing stopped in rivers to allow breeding and then fishermen move to ponds.

\section{Chita village}

It is not allowed to wash clothes or domestic appliances inside the rivers.

- At community level there is a specific calendar for fishing. From June to September fishing was done in rivers. Then, from January to May fishing stopped in rivers to allow breeding and then fishermen move to ponds.

- At individual level, before a person go to the river site, a person should specify on his own heart through special prayers the species, number of fish he want to fish and reason to go for fishing.

- It is not allowed to have sex nearby or inside the rivers

(b)

Box 1. (a) Traditional norms associated with rivers resources utilization in Upper Zigi catchment; (b) traditional norms associated with rivers resources utilization in Lower Mngeta catchment. 
and fishing are much conducted in Lower Mngeta catchment than in Upper Zigi catchment; while, ritual and sacrifices reported in both study areas. Those socio-cultural practices were governed by norms that regulated the utilization. Strong implementation of formal laws contributed to the loss of traditional norms. Fore stance, according to the traditional norms, such as bathing and washing near or inside rivers were not allowed in both study areas, but current people practicing without having fears despite the strong formal laws for managing aquatic resources to be formulated. This tells the significance of traditional institutions in managing catchment ecosystem.

The study recommends that ecological database should not only focus of the resources stock, but also on the resources utilization and this can successfully help to identify local actors with knowledge and skills who can be involved in planning and management. Doing so can also help to avoid the loss of ecological knowledge and skills that relate to aquatic resources utilization and management to the coming generation. Moreover, the study recognized if there would be a platform for exchanging knowledge between traditional and modern experts, some environmental challenges that many African countries faces can be solved. The study also believed that some of the information of socio-ecological system is left in the field. This is due to the use of etic approach only (means to different from community). Emic of approach (That means to be a part of community for sometimes) is the best approach of capturing social related data. Therefore, the study is recommend more research using emic approach on the traditional way of aquatic resources utilization particular to eastern arc catchments since the majority of available studies such as [13] [31] [67] [68] [69] focus on climate change, resources stocks, policies and aquatic ecosystem deterioration.

\section{Acknowledgements}

The financial support for this study came from the Pan-Africa University scholarship that is under Africa Union. Authors gratefully acknowledge the assistance from Tanzania Commission of Science and Technology, Rufiji Water Basin Authority and Pangani Water Basin Authority, the Local government of Muheza and Kilombero District of Tanzania and without forgetting Research Assistants Eric Ildefonce, Doris Mtumbuka, and Haron Ndaga.

\section{Conflicts of Interest}

The authors declare no conflicts of interest regarding the publication of this paper.

\section{References}

[1] Singh, R.V. (2000) Watershed Planning and Management. Yash Publishing House, New Delhi.

[2] Reed, M.S. (2008) Stakeholder Participation for Environmental Management: A Literature Review. Biological Conservation, 141, 2417-2431.

https://doi.org/10.1016/j.biocon.2008.07.014 
[3] Sivapalan, M., Savenije, H.H. and Blöschl, G. (2012) Socio-Hydrology: A New Science of People and Water. Hydrological Processes, 26, 1270-1276. https://doi.org/10.1002/hyp.8426

[4] Troy, T.J., Pavao-Zuckerman, M. and Evans, T.P. (2015) Debates-Perspectives on Socio-Hydrology: Socio-Hydrologic Modeling: Tradeoffs, Hypothesis Testing, and Validation. Water Resources Research, 51, 4806-4814. https://doi.org/10.1002/2015WR017046

[5] Gregory, K.J. (2006) The Human Role in Changing River Channels. Geomorpholo$g y$, 79, 172-191. https://doi.org/10.1016/j.geomorph.2006.06.018

[6] Klaver, I.J. (2011) Introduction: Water and Cultural Diversity. In: Water, Cultural Diversity, and Global Environmental Change, Springer, Berlin, 3-7. https://doi.org/10.1007/978-94-007-1774-9 1

[7] Johnston, B.R. (2013) Human Needs and Environmental Rights to Water: A Biocultural Systems Approach to Hydro Development and Management. Ecosphere, 4, 1-15. https://doi.org/10.1890/ES12-00370.1

[8] Elshafei, Y., Sivapalan, M., Tonts, M. and Hipsey, M.R. (2014) A Prototype Framework for Models of Socio-Hydrology: Identification of Key Feedback Loops and Parameterisation Approach. Hydrology and Earth System Sciences, 18, 2141-2166. https://doi.org/10.5194/hess-18-2141-2014

[9] Walker, W.E., Loucks, D.P. and Carr, G. (2015) Social Responses to Water Management Decisions. Environmental Processes, 2, 485-509.

https://doi.org/10.1007/s40710-015-0083-5

[10] Van Meter, K.J., Basu, N.B., McLaughlin, D.L. and Steiff, M. (2015) The Socio-Ecohydrology of Rainwater Harvesting in India: Understanding Water Storage and Release Dynamics at Tank and Catchment Scales. Hydrology and Earth System Sciences Discussions, 12, 12121-12165. https://doi.org/10.5194/hessd-12-12121-2015

[11] Krause, F. and Strang, V. (2016) Thinking Relationships through Water. Society \& Natural Resources, 29, 633-638. https://doi.org/10.1080/08941920.2016.1151714

[12] Van Emmerik, T.H.M., Li, Z., Sivapalan, M., Pande, S., Kandasamy, J., Savenije, H.H.G., Vigneswaran, S., et al. (2014) Socio-Hydrologic Modeling to Understand and Mediate the Competition for Water between Agriculture Development and Environmental Health: Murrumbidgee River Basin, Australia. Hydrology and Earth System Sciences, 18, 4239. https://doi.org/10.5194/hess-18-4239-2014

[13] Sivapalan, M. (2015) Debates-Perspectives on Socio-Hydrology: Changing Water Systems and the "Tyranny of Small Problems"-Socio-Hydrology. Water Resources Research, 51, 4795-4805. https://doi.org/10.1002/2015WR017080

[14] Muhar, A., Raymond, C.M., van den Born, R.J., Bauer, N., Böck, K., Braito, M., Mitrofanenko, T., et al. (2017) A Model Integrating Social-Cultural Concepts of Nature into Frameworks of Interaction between Social and Natural Systems. Journal of Environmental Planning and Management, 61, 756-777.

[15] Baron, J.S., Poff, N.L., Angermeier, P.L., Dahm, C.N., Gleick, P.H., Hairston, N.G., Steinman, A.D., et al. (2002) Meeting Ecological and Societal Needs for Freshwater. Ecological Applications, 12, 1247-1260. https://doi.org/10.1890/1051-0761(2002)012[1247:MEASNF]2.0.CO;2

[16] Falkenmark, M. (2003) Freshwater as Shared between Society and Ecosystems: From Divided Approaches to Integrated Challenges. Philosophical Transactions of the Royal Society of London B: Biological Sciences, 358, 2037-2049. https://doi.org/10.1098/rstb.2003.1386 
[17] Falkenmark, M. and Rockström, J. (2004) Balancing Water for Humans and Nature: The New Approach in Ecohydrology. Earthscan.

[18] Millennium Ecosytem Assessment (2005) Ecosystems and Human Well-Being: Wetlands and Water. World Resources Institute, Washington DC, 5.

[19] Ostrom, E. (2009) A General Framework for Analyzing Sustainability of Social-Ecological Systems. Science, 325, 419-422. https://doi.org/10.1126/science.1172133

[20] Braito, M.T., Böck, K., Flint, C., Muhar, A., Muhar, S. and Penker, M. (2017) Human-Nature Relationships and Linkages to Environmental Behaviour. Environmental Values, 26, 365-389. https://doi.org/10.3197/096327117X14913285800706

[21] Díaz, S., Demissew, S., Carabias, J., Joly, C., Lonsdale, M., Ash, N., Bartuska, A., et al. (2015) The IPBES Conceptual Framework-Connecting Nature and People. Current Opinion in Environmental Sustainability, 14, 1-16. https://doi.org/10.1016/j.cosust.2014.11.002

[22] Bekbolotov, J.B. (2007) Public Participation in Water Resources Management.

[23] Pan, A., Bosch, D. and Ma, H. (2017) Assessing Water Poverty in China Using Holistic and Dynamic Principal Component Analysis. Social Indicators Research, 130, 537-561. https://doi.org/10.1007/s11205-015-1191-3

[24] Ludwig, F., Slobbe, E. and Cofino, W. (2014) Climate Change Adaptation and Integrated Water Resource Management in the Water Sector. Journal of Hydrology, 518, 235-242. https://doi.org/10.1016/j.jhydrol.2013.08.010

[25] Meinzen-Dick, R.S. and Pradhan, R. (2001) Implications of Legal Pluralism for Natural Resource Management. IDS Bulletin, 32, 10-17. https://doi.org/10.1111/j.1759-5436.2001.mp32004002.x

[26] Lein, H. and Tagseth, M. (2009) Tanzanian Water Policy Reforms-Between Principles and Practical Applications. Water Policy, 11, 203-220. https://doi.org/10.2166/wp.2009.024

[27] Sokile, C.S., Mwaruvanda, W. and Van Koppen, B. (2005) Integrated Water Resource Management in Tanzania: Interface between Formal and Informal Institutions. Conference African Water Laws: Plural Legislative Frameworks for Rural Water Management in Africa, Johannesburg, South Africa, 26-28, January 2005, 26-28.

[28] UNDP (2017) Conserving Ruvu Water Catchments to Enhance Water Availability. http://www.tz.undp.org

[29] URT (United Republic of Tanzania) (2002) National Water Policy. Ministry of Water and Livestock Development, United Republic of Tanzania, Dar es Salaam, 49 p.

[30] Turpie, J., Ngaga, Y. and Karanja, F. (2003) A Preliminary Economic Assessment of Water Resources of Pangani River Basin, Tanzania. Economic Value, Incentives for Sustainable Use and Mechanisms for Financing Management. IUCN-East Africa Region Office and Pangani Basin Water Office.

[31] Lalika, M.C., Meire, P., Ngaga, Y.M. and Chang'a, L. (2015) Understanding Watershed Dynamics and Impacts of Climate Change and Variability in the Pangani River Basin, Tanzania. Ecohydrology \& Hydrobiology, 15, 26-38. https://doi.org/10.1016/j.ecohyd.2014.11.002

[32] Wilson, N.J., Walter, M.T. and Waterhouse, J. (2015) Indigenous Knowledge of Hydrologic Change in the Yukon River Basin: A Case Study of Ruby, Alaska. Arctic, 68, 93-106. https://doi.org/10.14430/arctic4459

[33] Caillon, S., Cullman, G., Verschuuren, B. and Sterling, E. (2017) Moving beyond the 
Human-Nature Dichotomy through Biocultural Approaches: Including Ecological Well-Being in Resilience Indicators. Ecology and Society, 22, 27. https://doi.org/10.5751/ES-09746-220427

[34] Iddi, S. (1998) Eastern Arc Mountains and Their National and Global Importance. Journal of East African Natural History, 87, 19-26. https://doi.org/10.2982/0012-8317(1998)87[19:EAMATN]2.0.CO;2

[35] URT (United Republic of Tanzania) (2010) Baseline Study of the Kilombero Valley Ramsar Site, Ifakara, Morogoro Tanzania. Department of Zoology and Wildlife Conservation, University of Dar es Salaam, Dar es Salaam, Manual: AAS-2014-46, $52 \mathrm{p}$.

[36] Nindi, S.J., Maliti, H., Bakari, S., Kija, H. and Machoke, M. (2014) Conflicts over Land and Water Resources in the Kilombero Valley Floodplain, Tanzania. African Study Monographs, Supplementary Issue, 50, 173-190.

[37] MNRT (Tanzania Ministry of Natural Resources and Tourism) (1998) National Forest Policy (March).

[38] URT (United Republic of Tanzania) (2016) Ministry of Agriculture Livestock and Fisheries: The Tanzanian Fisheries Sector, Challenge and Opportunities, 40 p.

[39] Ricketts, T.H., Dinerstein, E., Boucher, T., et al. (2005) Pinpointing and Preventing Imminent Extinctions. Proceedings of the National Academy of Sciences of the United States of America, 102, 18497-18501.

https://doi.org/10.1073/pnas.0509060102

[40] Balama, C., Augustino, S., Mwaiteleke, D., Lusambo, L.P. and Makonda, F. (2016) Economic Valuation of Nontimber Forest Products under the Changing Climate in Kilombero District, Tanzania. International Journal of Forestry Research, 2016, Article ID: 7893143. https://doi.org/10.1155/2016/7893143

[41] Fadhilia, B., Liwa, E. and Shemdoe, R. (2016) Indigenous Knowledge of Zigi Community and Forest Management Decision-Making\&58; a Perspective of Community Forest Interaction. Journal of Natural Resources and Development, 6, 14-21. https://doi.org/10.5027/jnrd.v6i0.03

[42] Kuwabara, T. (2014) PAR and Mixed Methods (1). LSdlc.docx. 1 p.

[43] Nurick, R. and Apgar, M. (2014) Participatory Action Research: Guide for Facilitators. CGIAR Research Program on Aquatic Agricultural Systems, Penang.

[44] International Institute for Environment and Development (IIED) (2017) Participatory Resource Mapping Tool Kit. 4 p.

[45] Montanari, A., Young, G., Savenije, H.H.G., Hughes, D., Wagener, T., Ren, L.L., Blöschl, G., et al. (2013) "PantaRhei-Everything Flows": Change in Hydrology and Society-The IAHS Scientific Decade 2013-2022. Hydrological Sciences Journal, 58, 1256-1275. https://doi.org/10.1080/02626667.2013.809088

[46] Vaismoradi, M., Turunen, H. and Bondas, T. (2013) Content Analysis and Thematic Analysis: Implications for Conducting a Qualitative Descriptive Study. Nursing \& Health Sciences, 15, 398-405. https://doi.org/10.1111/nhs.12048

[47] Zimmerman, E.W. (1951) World Resources and Industries: A Functional Appraisal of Availability of Agricultural and Industrial Resources.

[48] Dorresteijn, I., Loos, J., Hanspach, J. and Fischer, J. (2015) Socioecological Drivers Facilitating Biodiversity Conservation in Traditional Farming Landscapes. Ecosystem Health and Sustainability, 1, 1-9. https://doi.org/10.1890/EHS15-0021.1

[49] Persic, A. and Martin, G. (2008) Links between Biological and Cultural Diversity. 48 p.

[50] Maffi, L. (2001) Introduction: On the Interdependence of Biological and Cultural 
Diversity. On Biocultural Diversity. Linking Language, Knowledge and the Environment. Smithsonian Institute, Washington DC, 1-50.

[51] Harmon, D. (2002) In Light of Our Differences: How Diversity in Nature and Culture Makes Us Human. Smithsonian Institution Press, Washington DC.

[52] Harmon, D. (2001) On the Meaning and Moral Imperative of Diversity. In: Maffi, L., Ed., On Biological Diversity: Linking Languages, Knowledge, and the Environment, Smithsonian Institution Press, Washington DC, 53-70.

[53] Kassam, K.A. (2009) Biocultural Diversity and Indigenous Ways of Knowing: Human Ecology in the Arctic. University of Calgary Press, Calgary, 292 p.

[54] Ujjania, N.C. and Mistry, C.A. (2012) Environmental Impact of Idol Immersion on Tapiriver (India). International Journal of Geology, Earth and Environmental Sciences, 2, 11-16.

[55] Torgersen, E.H. (2018) Waters of Destruction: Mythical Creatures, Boiling Pots and Tourist Encounters at Wailuku River in Hilo, Hawai'i. In: Wagner, J.R. and Jacka, J.K., Eds., Island Rivers. Fresh Water and Place in Oceania, ANU Press, Canberra, 165-186. https://doi.org/10.22459/IR.06.2018.07

[56] Cregan-Reid, V. (2004) Water Defences. Critical Survey, 16, 33-47. https://doi.org/10.3167/001115704782351591

[57] Kokolakakis, T., Pappous, A.S. and Meadows, S. (2015) The Impact of the Free Swimming Programme in a Local Community in the South East of England: Giving with One Hand, Taking Away with the Other. International Journal of Environmental Research and Public Health, 12, 4461-4480.

https://doi.org/10.3390/ijerph120404461

[58] Ito, G.H. (2014) Barriers to Swimming and Water Safety Education for African Americans. International Journal of Aquatic Research and Education, 8, 4. https://doi.org/10.25035/ijare.08.03.04

[59] Martin, S.M., Lorenzen, K. and Bunnefeld, N. (2013) Fishing Farmers: Fishing, Livelihood Diversification and Poverty in Rural Laos. Human Ecology, 41, 737-747. https://doi.org/10.1007/s10745-013-9567-y

[60] Chapman, M.D. (1987) Women's Fishing in Oceania. Human Ecology, 15, 267-288. https://doi.org/10.1007/BF00888026

[61] Zidana, A., Kaunda, E., Phiri, A., Khalil-Edriss, A., Matiya, G. and Jamu, D. (2007) Factors Influencing Cultivation of the Lilongwe and Linthipe River Banks in Malawi: A Case Study of Salima District. Journal of Applied Sciences, 7, 3334-3337. https://doi.org/10.3923/jas.2007.3334.3337

[62] Hardlife, Z., Talent, M. and Oswell, R. (2017) Streambank Cultivation along Chiredzi River in Zaka District, Zimbabwe: An Activity Widely Practiced But Institutionally Condemned. International Journal of Agriculture, Environment and Bioresearch, 2, 79-96.

[63] Sharma, D. and Kansal, A. (2011) Current Condition of the Yamuna River: An Overview of Flow, Pollution Load, and Human Use. Yamuna River: A Confluence of Waters, a Crisis of Need. $17 \mathrm{p}$.

[64] Berkes, F. and Folke, C. (1998) Linking Social and Ecological Systems for Resilience and Sustainability. In: Berkes, F., Folke, C. and Colding, J., Eds., Linking Social and Ecological Systems: Management Practices and Social Mechanisms for Building Resilience, Cambridge University Press, New York, 27 p.

[65] Lawrence, A. (2008) Experiences with Participatory Conservation in Post-Socialist Europe. International Journal of Biodiversity Science \& Management, 4, 179-186. 
https://doi.org/10.3843/Biodiv.4.4:1

[66] Ntongani, W.A., Munishi, P.K., More, S.R. and Kashaigili, J.J. (2014) Local Knowledge on the Influence of Land Use/Cover Changes and Conservation Threats on Avian Community in the Kilombero Wetlands, Tanzania. Open Journal of Ecology, 4, 723. https://doi.org/10.4236/oje.2014.412062

[67] Kabuye, A.M. (2015) The Impact of Migrant Livestock Keepers on the Natives and Natural Resources of Kilombero Valley, in Tanzania: A Case of Kilombero District. Doctoral Dissertation, Mzumbe University, Mvomero, $92 \mathrm{p}$.

[68] Seki, H.A., Shirima, D.D., Courtney Mustaphi, C.J., Marchant, R. and Munishi, P.K. (2018) The Impact of Land Use and Land Cover Change on Biodiversity within and Adjacent to Kibasira Swamp in Kilombero Valley, Tanzania. African Journal of Ecology, 56, 518-527. https://doi.org/10.1111/aje.12488

[69] Lacerda, L.D.D. and Malm, O. (2008) Mercury Contamination in Aquatic Ecosystems: An Analysis of the Critical Areas. Estudosavançados, 22, 173-190. https://doi.org/10.1590/S0103-40142008000200011 